\title{
Experimental demonstration of plasticity in the heat shock response of the intertidal mussel Mytilus californianus
}

\author{
Patricia M. Halpin ${ }^{1, *}$, Bruce A. Menge ${ }^{3}$, Gretchen E. Hofmann ${ }^{1,2}$ \\ ${ }^{1}$ Marine Science Institute, and ${ }^{2}$ Department of Ecology, Evolution, and Marine Biology, University of California, \\ Santa Barbara, California 93106, USA \\ ${ }^{3}$ Department of Zoology, Oregon State University, Corvallis, Oregon 97331-2914, USA
}

\begin{abstract}
We report the results of a reciprocal transplant experiment that tested plasticity in the heat shock response (HSR) of an intertidal mussel, Mytilus californianus (Conrad), in its natural habitat. We predicted that mussels inhabiting the upper edge of their vertical distribution, the high intertidal mussel bed, would display physiological signatures of greater thermal stress, specifically higher levels of an inducible heat shock protein isoform, Hsp72, and a higher temperature at which de novo synthesis of Hsp72 begins (threshold induction temperature). However, due to limits in physiological plasticity, we also predicted that the HSR of mussels transplanted between high and low areas would resemble that of mussels from both their source and their transplant microhabitats. The transplant experiment was conducted on the central coast of Oregon; mussels were transplanted between and within the high and low intertidal areas of the mussel bed in May 2001 and collected for measurement in August 2001. In addition, mussels from the natural populations of these areas were collected for comparison with experimental groups in May and August 2001. Using dissected gill tissue from each group of mussels, threshold induction temperatures and cellular levels of isoforms of the $70 \mathrm{kDa}$ Hsp gene family were measured using in vitro metabolic labeling and immunochemical detection, respectively. The results demonstrated that the HSR was highly plastic over small spatial scales in the rocky intertidal habitat, although the compensation of the transplanted mussels was not perfect in every group. For example, although the induction temperature range was similar among mussels either collected from, or transplanted to the high-bed, those transplanted to the low-bed from the high zone displayed a broader range of induction temperatures, indicating that some mussels retained elements in their HSR with greater resemblance to mussels from their source microhabitat than those in their new microhabitat. Levels of inducible Hsp72 were greater in mussels from the high-bed than the low-bed, indicating that organisms from closely spaced microhabitats experience different levels of protein damage from environmental stress.
\end{abstract}

KEY WORDS: Heat shock proteins $\cdot \operatorname{Hsp} 70 \cdot$ Mytilus californianus $\cdot$ Plasticity $\cdot$ Reciprocal transplant Rocky intertidal zone $\cdot$ Thermotolerance

Resale or republication not permitted without written consent of the publisher

\section{INTRODUCTION}

Organismal survival within a habitat depends on a combination of canalized and plastic traits. On one hand, selection may act so that only organisms of a certain genotype survive after entering the habitat, as in post-settlement selection. Alternatively, survival may be enhanced through pathways of developmental plasticity acting on a suite of traits that may or may not be plastic in the adult phenotype, and highly plastic traits that may be modified even in the adult organism in response to environmental change. Since many marine animals are sessile or have low mobility, physiological mitigation of environmental stress is critical, 
especially in areas such as the rocky intertidal zone, where physical conditions change dramatically with the tides. Therefore, elucidating the degree of plasticity in physiological stress responses would enhance our basic understanding of organismal survival in the marine environment.

In the rocky intertidal zone, organisms experience wide fluctuations in body temperature (Hofmann \& Somero 1996b, Helmuth 1998, 1999, Tomanek \& Somero 1999, Dahlhoff et al. 2001). A central component of the physiological response to thermal stress, the heat shock response (HSR), is comprised of both constrained and plastic elements, making it an ideal subject to study in the context of organismal response to the environment (Bettencourt et al. 1999, Dahlhoff \& Rank 2000, Buckley et al. 2001). The heat shock response (HSR) occurs across kingdoms and phyla as an ubiquitous mechanism for repairing protein damage and increasing stress tolerance (Lindquist 1986, Feder \& Hofmann 1999). After a stress has caused conformational changes in proteins, such as denaturation from heat, the inducible isoforms of heat shock proteins (Hsps) are synthesized. Inducible Hsps bind to damaged proteins, prevent their cytotoxic aggregation, and help refold proteins to rescue their function. Constitutive isoforms of Hsps perform a variety of protein chaperoning tasks, including those associated with normal cell function, and may be expressed under non-stressful conditions. High levels of inducible Hsps therefore indicate high levels of protein damage, and increased tolerance of further thermal stress (Lindquist 1986, Feder \& Hofmann 1999). Under current models of the HSR, increases in cellular Hsp levels will also increase the temperature at which de novo synthesis of inducible Hsps commences, the threshold induction temperature (Morimoto 1998).

Isoforms of proteins in the Hsp70 family confer thermotolerance in nature and under ecologically relevant conditions in the laboratory (Feder \& Hofmann 1999, Krebs \& Bettencourt 1999). The threshold induction temperature varies between species, within species, and also as a function of the thermal history of the organism (Hofmann \& Somero 1996a, Feder \& Hofmann 1999, Tomanek \& Somero 1999, 2000, Buckley et al. 2001). A large body of work has established that some of this variation in the HSR, even within a population, is genetically controlled, though the HSR is heavily modulated through an organism's interaction with its environment (Feder 1999, Krebs \& Bettencourt 1999). Though studies have documented variation in levels of Hsps in the field (Feder \& Hofmann 1999), few have transplanted organisms between environments to examine alteration in the HSR in nature (Tedengren et al. 1999, Dahlhoff et al. 2001). In this study we use the rocky intertidal zone as a model system for investigat- ing source environment effects on the HSR. Intertidal areas present a unique opportunity to investigate biochemical plasticity as the population distributions are compressed in the vertical direction, along the tidal gradient. Thus survival at the upper shore limit may be mediated by wholly different organismal traits than survival at the lower shore limit, though these microhabitats may be separated by only a few meters. Here we examine the HSR in the California mussel Mytilus californianus (Conrad) an abundant, habitat-forming organism with a history of ecological and physiological study (Bayne 1976, Gosling 1992).

Mytilus californianus dominates the mid intertidal zone on temperate rocky shores of the northeastern Pacific Ocean (Paine 1974, Menge 2000, Sagarin \& Gaines 2002). The upper tidal level limits of M. californianus distribution are hypothesized to be set by interacting physical stresses such as thermal stress, desiccation and emersion time (Bayne et al. 1976, Suchanek 1978, Tsuchiya 1983, Iwasaki 1995). Mussels tolerate emersion by reducing their metabolic rate and using anaerobic metabolic pathways (Bayne 1976, Bayne et al. 1976, Widdows et al. 1979, Widdows \& Shick 1985). High intertidal mussels may compensate for longer emersion times with increased metabolic rates (Moon \& Pritchard 1970). Despite mechanisms for physiological compensation during and after aerial emersion, mussel body temperatures can rise to the level where protein damage occurs (Hofmann \& Somero 1995). Mussel body temperatures are consistently higher in the upper portion of the bed as compared to the lower, and mortality due to heat events has been observed to be greater in high intertidal areas (Tsuchiya 1983, P. M. Halpin \& G. E. Hofmann unpubl. data), indicating heat stress increases with shore height. In contrast, the lower vertical limit of $M$. californianus' distribution is set through species interactions such as predation (Coe \& Fox 1942, Paine 1976, Menge et al. 1994, Robles 1997).

Previous investigations of intertidal mussels revealed inter- and intra-specific differences in the HSR. For example, in a comparison of 2 congeneric species, the more southerly distributed Mytilus galloprovincialis had lower levels of Hsp70 and higher induction temperatures after $8 \mathrm{wk}$ of cold acclimation than did its northern congener $M$. trossulus (Hofmann \& Somero 1996a), indicating genetic, non-plastic differences in the HSR. Within a species, M. californianus collected from different microhabitats within a site can have significantly different levels of Hsp70 isoforms and induction temperatures (Roberts et al. 1997, Helmuth \& Hofmann 2001, Halpin et al. 2002). Mussels within populations of several species alter Hsp levels over seasonal and shorter time scales (Hofmann \& Somero 1995, Buckley et al. 2001, Halpin et al. 2002), demon- 
strating temporal plasticity in adults within their microhabitat.

Here we investigate differences in the HSR between mussels inhabiting the upper and lower edges of their vertical intertidal distribution, and the plasticity of that response. We investigate 2 predictions: (1) mussels at the upper vertical limit of their distribution will have higher levels of Hsp72 and higher induction temperatures; (2) due to potential limits to physiological plasticity, the biochemical response to stress, i.e. Hsp72 levels and threshold induction temperatures, of mussels transplanted between the edges of their vertical distribution will more closely resemble mussels from their source environment than mussels from the new environment. To test these hypotheses, we conducted a transplant experiment between the upper and lower edges of a mussel bed in Oregon.

\section{MATERIALS AND METHODS}

Study site. Experiments were conducted at Strawberry Hill, Oregon, USA ( $44^{\circ} 15^{\prime} \mathrm{N}, 124^{\circ} 6^{\prime} 36^{\prime \prime} \mathrm{W}$, NAD27). The site consists of broad rocky benches where the California mussel Mytilus californianus dominates the mid intertidal zone, forming dense beds (Menge 1992, Menge et al. $1997 \mathrm{a}, \mathrm{b})$. The study area included a low-bed area at the lower tidal edge of $M$. californianus distribution, and a high-bed area at the upper edge. Previous measures of mussel body temperatures from the central Oregon coast indicate a peak during mid-summer (Elvin \& Gonor 1979, Helmuth 2002). Thus we began the transplant experiment in May, as climate conditions transitioned into spring, and ended in August.

Transplant experiment. To compare the plasticity of the HSR in mussel populations at a small spatial scale, we performed a reciprocal transplant experiment on May 25, 2001, at Strawberry Hill, OR. Adult mussels of 5 to $7 \mathrm{~cm}$ length were collected from the high-bed and low-bed areas of the mussel zone. Mussels were tagged by placing a small amount of marine epoxy (Z-spar) on the mussel shell and embedding a labeled plastic tag (Dymo label), color-coded for tidal height. Twenty mussels were transplanted per treatment. Treatments were transplants (1) from the high-bed to the low-bed (HL), (2) from high-bed back into the high-bed $(\mathrm{HH}),(3)$ from the low-bed to the high-bed (LH), and (4) from the low-bed back into the low-bed (LL). Mussels were transplanted by firmly placing them anterior end down at haphazard locations within the designated mussel bed area. They were held in place by the surrounding mussels until they could reattach via byssal thread production. We designated 6 mussels as our collection number after consideration of the logistical constraints of measuring many induction temperature profiles over a short time period. We transplanted excess mussels to compensate for losses that might occur if mussels dislodged before they could adequately reform their byssal thread attachment. At the start of the experiment, 6 mussels from each area were collected to establish a baseline for the physiological measurements described below (hereafter natural population, high and low, May; coded as NPHMay and NPL-May, respectively). During August 2001, 6 mussels from each of the 4 transplant treatments were collected for analysis with the exception of the LL treatment, where only 4 tagged individuals could be found. In addition to the transplants, 6 untagged, unmanipulated mussels were also collected from the high-bed and the low-bed for analysis (NPH-Aug and NPL-Aug, respectively). Induction temperatures and total levels of Hsp70 isoforms (Hsp72 and Hsc75) were determined for collected mussels.

Threshold induction temperatures. To detect the de novo synthesis of Hsp70 in response to heat stress, we metabolically labeled gill tissue in vitro. Gills were dissected out of living mussels, separated into 8 subsections and placed in $1 \mathrm{ml}$ of artificial seawater (ASW). Additional gill tissue was flash frozen on dry ice for subsequent immunochemical detection of Hsp70 (see below). The 8 sub-samples of live gill tissue were exposed separately to temperatures of $11,15,19$, $22,23.3,24.8,27$ and $30^{\circ} \mathrm{C}$ for $1 \mathrm{~h}$. After exposure, live tissue was held at $11^{\circ} \mathrm{C}$ and incubated with $27.5 \mu \mathrm{Ci}$ of ${ }^{35} \mathrm{~S}$-labeled cysteine/methionine for $4 \mathrm{~h}$. After $4 \mathrm{~h}$, tissue was rinsed twice in ASW and homogenized in $200 \mathrm{ml}$ SDS homogenizing buffer $\left(50 \mathrm{mM}\right.$ Tris- $\mathrm{HCl}_{\text {, }}$ $\mathrm{pH} 6.8 ; 4 \%$ sodium dodecyl sulfate; $1 \mathrm{mmol} \mathrm{l}^{-1}$ ethylenediaminetetraacetic acid, EDTA; $1 \mathrm{mmol} \mathrm{l}^{-1}$ phenylmethylsulfonylfluoride, PMSF). At this point, tissue was no longer metabolically active. Homogenates were heated at $100^{\circ} \mathrm{C}$ for $5 \mathrm{~min}$, and centrifuged at $14000 \times g$ for $15 \mathrm{~min}$. Supernatants were retained for analysis, and stored at $-20^{\circ} \mathrm{C}$. Total counts of incorporated amino acid were determined with a scintillation counter. Samples containing equal amounts of radioactivity were loaded onto a $10 \%$ polyacrylamide gel and separated using SDS polyacrylamide gel electrophoresis (SDS-PAGE). Gels were soaked in $\mathrm{EN}^{3} \mathrm{HANCE}$ autoradiography enhancer (PerkinElmer) for $1 \mathrm{~h}$, then dried and exposed for $15 \mathrm{~h}$ at $-70^{\circ} \mathrm{C}$ to $\mathrm{X}$-ray film (Kodak MS Film) in conjunction with an intensifying screen (Kodak Biomax TranScreen LE). Developed films were quantified by scoring the sub-samples visually. The induction temperature was recorded as being between the highest experimental temperature with no band in the $70 \mathrm{kDa}$ range and the lowest temperature with a band. For example in Fig. 1, no bands in the $70 \mathrm{kDa}$ range occur in samples incubated at or below $23.3^{\circ} \mathrm{C}$, and do occur in all samples incubated at or 


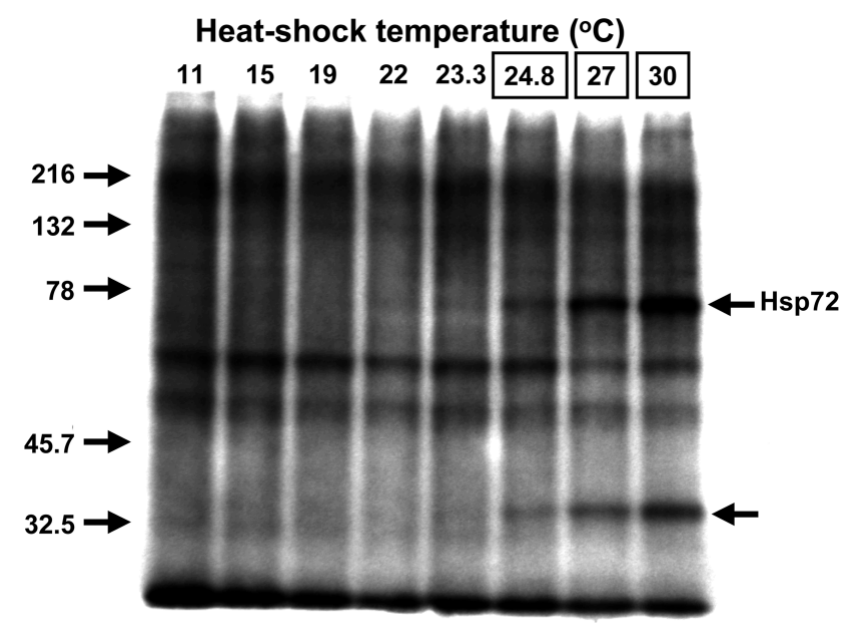

Fig. 1. Mytilus californianus. Threshold induction temperature in a single experimental mussel transplanted from the high portion of the mussel bed back into the high portion of the mussel bed (HH treatment group). Each lane contains ${ }^{35}$ S-radiolabeled tissue homogenate from one incubation temperature (labeled at top of lanes). In this example, de novo synthesis of Hsp72 occurs in samples incubated at 24.8, 27, and $30^{\circ} \mathrm{C}$ (boxed temperatures, top right arrow). Note also that de novo synthesis of a lower molecular weight Hsp (approx. $33 \mathrm{kDa}$ ) also begins at and above $24.8^{\circ} \mathrm{C}$ (lower right arrow). Left arrows indicate protein size $(\mathrm{kDa})$

above $24.8^{\circ} \mathrm{C}$. Therefore, Hsp70 induction occurs at a temperature between 23.3 and $24.8^{\circ} \mathrm{C}$.

Hsp70 isoform levels. To quantify levels of Hsp70 isoforms in collected mussels, tissue preparation, protein determination, and Western blotting analysis were performed as described previously (Hofmann \& Somero 1995, Helmuth \& Hofmann 2001, Halpin et al. 2002), except for the following. Proteins were electrophoretically separated on a 7.5\% SDS-polyacrylamide gel (5 $\mu \mathrm{g}$ protein per lane). Each gel also contained a sample of Mytilus californianus gill tissue homogenate (5 $\mu \mathrm{g})$ pooled from animals heat shocked in the laboratory as a standard and positive control, and prestained molecular weight markers (kaleidoscope prestained standards, broad range; Biorad). Proteins were transferred for $1 \mathrm{~h}$ at $100 \mathrm{~V}$ to nitrocellulose membrane (Osmonics NitroBind $45 \mu \mathrm{m}$ ) using the wet transfer method in a Mini-Transblot unit (Biorad) in a transfer buffer containing $25 \mathrm{mmol} \mathrm{l}^{-1}$ Tris base, $192 \mathrm{mmol} \mathrm{l}^{-1}$ glycine and $20 \%$ methanol. After development in SuperSignal according to the manufacturer's instructions (Pierce), blots were covered in plastic wrap, visualized in a Versadoc multi-imager (Biorad) and quantified using QuantityOne software. Two isoforms could be visualized on the blots for each sample, the constitutive isoform Hsc75 and the inducible isoform Hsp72 (Helmuth \& Hofmann 2001). Intensity of sample bands was divided by intensity of the $M$. californianus standard to allow comparison between gels.

Statistical analysis. To analyze the relative amount of Hsp72 and Hsc75, data were log transformed to achieve normality (Shapiro-Wilkes Goodness of Fit test, $\mathrm{p}[<\mathrm{W}]=0.1967$ ). Hsp72 and Hsc75 levels in natural populations of mussels from the high- and the lowbed at the beginning and end of the experiment were compared separately using 2-way ANOVA with time (May, August) and level (high-bed, low-bed) as factors. For mussels collected in August, Hsp72 and Hsc75 were compared using 1-way ANOVA with group as the factor (HH, HL, LH, LL, NPH-Aug and NPL-Aug). For all ANOVAs and $t$-tests, variances across groups were not significantly different, meeting ANOVA assumptions, except for the comparison of natural population Hsc75 levels. Induction temperature data are presented as descriptive of the range of temperature over which a collection group begins de novo synthesis of Hsp72.

\section{RESULTS}

Within the natural population, mussels displayed induction patterns that indicate potential effects of microhabitat and time (Fig. 2). Across the group, mussels began de novo synthesis of Hsp72 between 15 and $30^{\circ} \mathrm{C}$. In May, mussels from both the high- and low-bed areas exhibited similar patterns of induction, initiating synthesis between 23.3 and $30^{\circ} \mathrm{C}$ (Fig. 2A). One mussel from NPL-May could not be quantified, as tissue from the highest temperature treatments produced no radiolabeled protein, including proteins typically expressed at all temperatures (see Fig. 1), indicating possible tissue death during labeling. However, no Hsp72 was synthesized at lower temperatures with good labeling, indicating an induction temperature over $24.8^{\circ} \mathrm{C}$. This individual was excluded from analysis of induction temperature, but included in analysis of isoform levels, as sample damage was unrelated to the sample collected for western blotting. Mussels collected from the low-bed in August had lower induction temperatures $\left(15\right.$ to $\left.23.3^{\circ} \mathrm{C}\right)$ than those from the highbed $\left(22\right.$ to $\left.30^{\circ} \mathrm{C}\right)$ and those from the low- and the highbed collected in May (Fig. 2B). The mussels collected from the high-bed area in August included 2 individuals that showed synthesis of Hsp72 at all experimental temperatures, indicating that these individuals had been heat shocked prior to collection and were already synthesizing Hsps. This was also observed in 1 mussel from the high- to high-bed $(\mathrm{HH})$ experimental group. These individuals were excluded from induction temperature data, but included in analysis of endogenous Hsp70 levels. 

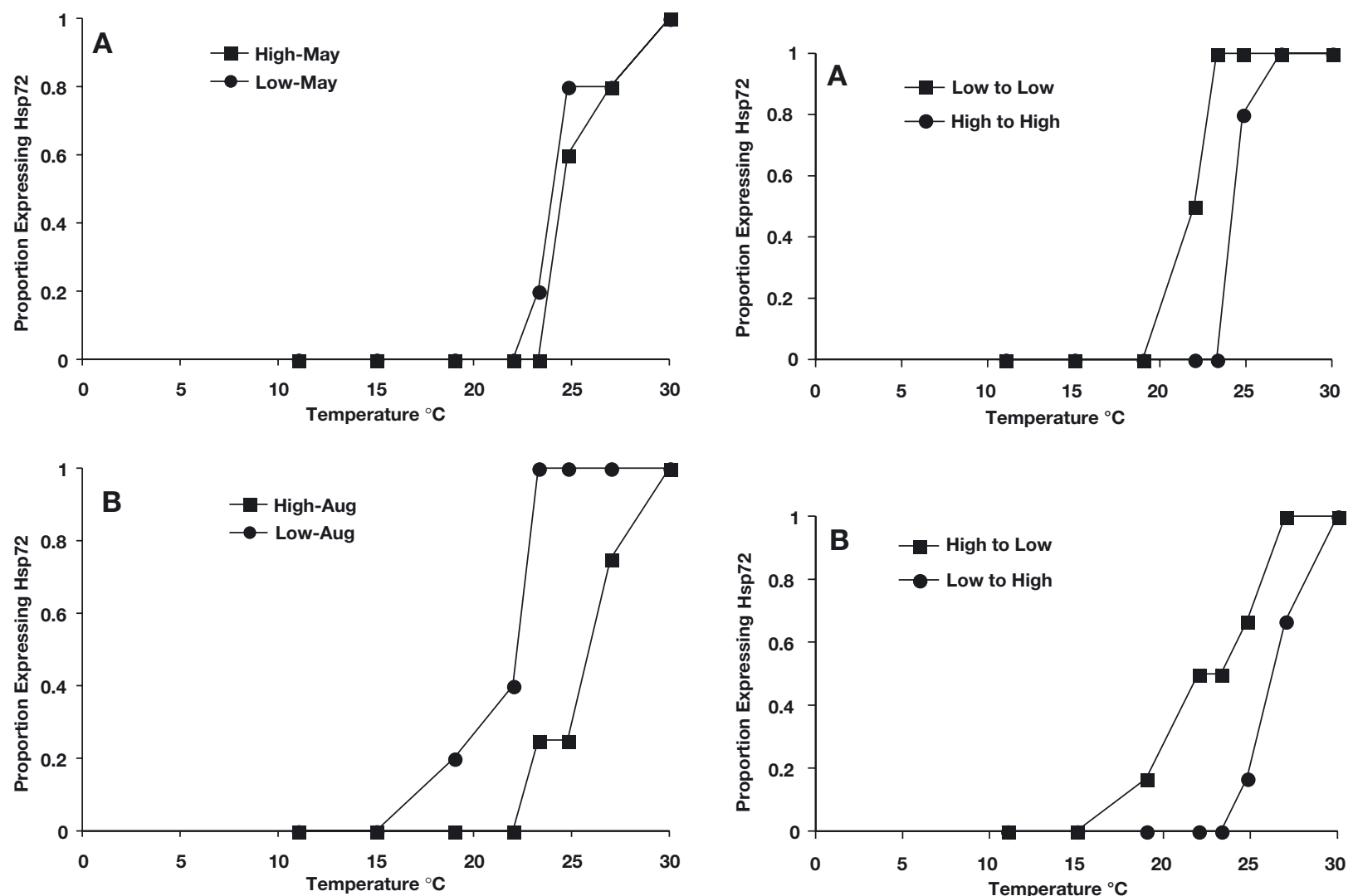

Fig. 2. Mytilus californianus. Induction temperature profiles of mussels from natural populations. De novo synthesis of Hsp72 versus temperature ${ }^{\circ} \mathrm{C}$ for natural population mussels collected from high and low areas of the mussel bed in (A) May and (B) August. For all collection groups, $\mathrm{N}=6$, except for NPL-May where $\mathrm{N}=5$, and NPH-Aug, where $\mathrm{N}=4$

In the experimental groups, the induction temperatures of the within-level transplants (HH, LL, Fig. 3A) and the low to high (LH, Fig. 3B) transplant group closely resemble the patterns observed in mussels from the natural populations collected concurrently in August (Fig. 2B). Specifically, mussels collected from the low-bed (NPLAug , Fig. 2B; LL, Fig. 3A) began de novo synthesis of Hsp72 at lower temperatures than those collected from the high-bed (NPH-Aug, Fig. 2B; HH and LH, Fig. 3). In contrast, the mussels transplanted from the high- to the low-bed displayed induction temperatures that spanned a broad range, from 15 to $27^{\circ} \mathrm{C}$ (Fig. 3B). This $12^{\circ} \mathrm{C}$ range is broader than the $8^{\circ} \mathrm{C}$ range observed in the group with next greatest value (in NPH-Aug, Fig. 2B).

Our results revealed small-scale spatial and temporal differences in levels of the inducible isoform, Hsp72, in mussels (Fig. 4, ANOVA, $\mathrm{r}^{2}=0.36$, model $\mathrm{p}=$ 0.0437). Bed level affected levels of Hsp72 in natural populations (2-way ANOVA; time, $\mathrm{p}=0.1697$; level, $\mathrm{p}=0.0091$; level $\times$ time, $\mathrm{p}=0.9314)$. In comparing groups within the August collection of experimental

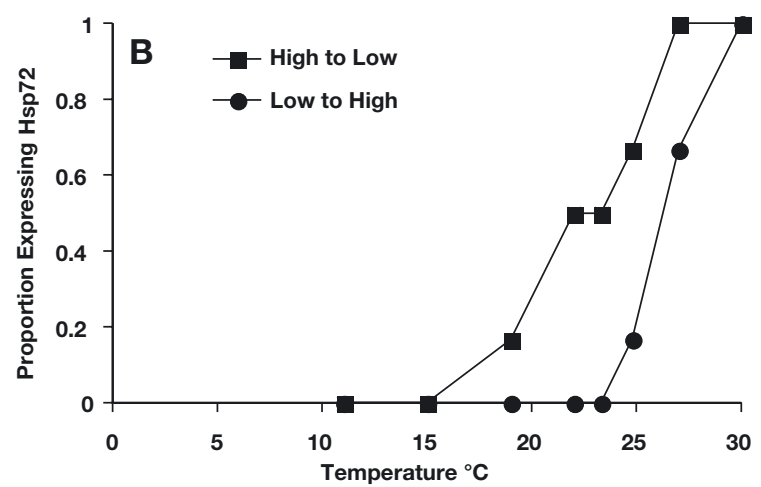

Fig. 3. Mytilus californianus. Induction temperature profiles in experimental mussels. De novo synthesis of Hsp72 versus temperature ${ }^{\circ} \mathrm{C}$ for mussels transplanted (A) within a mussel bed area (high to high and low to low) and (B) between areas (high to low and low to high). For all collection groups, $\mathrm{N}=6$, except for $\mathrm{HH}$, where $\mathrm{N}=5$, and $\mathrm{LL}$, where $\mathrm{N}=4$

and natural populations, differences between groups were marginally non-significant (1-way ANOVA, p = 0.0647), although the trend was for higher Hsp72 levels in mussels collected from the high-bed (Fig. 4). When grouped by bed level, e.g. grouping LH, HH and NPH-Aug together, high-bed mussels had significantly higher levels of Hsp72 than those collected from the low-bed ( $t$-test, $\mathrm{r}^{2}=0.24, \mathrm{p}=0.0045$ ).

For the constitutive isoform, Hsc75, mussels from the natural population exhibited slight variation in space and time (Fig. 5, ANOVA, $\mathrm{r}^{2}=0.33$, model $\mathrm{p}=0.0616$ ). Hsc75 tended to vary with time $(p=0.0496)$, and with tidal level $(p=0.0513)$. The level $\times$ time interaction was not significant $(\mathrm{p}=0.416)$. In the August collections of experimental and natural populations, groups differed from each other (ANOVA, $p=0.0392$ ). Similar to Hsp72 levels, when combined, high groups (NPH-Aug, $\mathrm{HH}, \mathrm{LH}$ ) differed from low groups (NPL-Aug, HL, LL) $\left(t\right.$-test, $\left.\mathrm{r}^{2}=0.24, \mathrm{p}<0.0041\right)$, indicating that differences between high- and low-bed Hsc75 might be more clearly distinguished with greater sample sizes. 

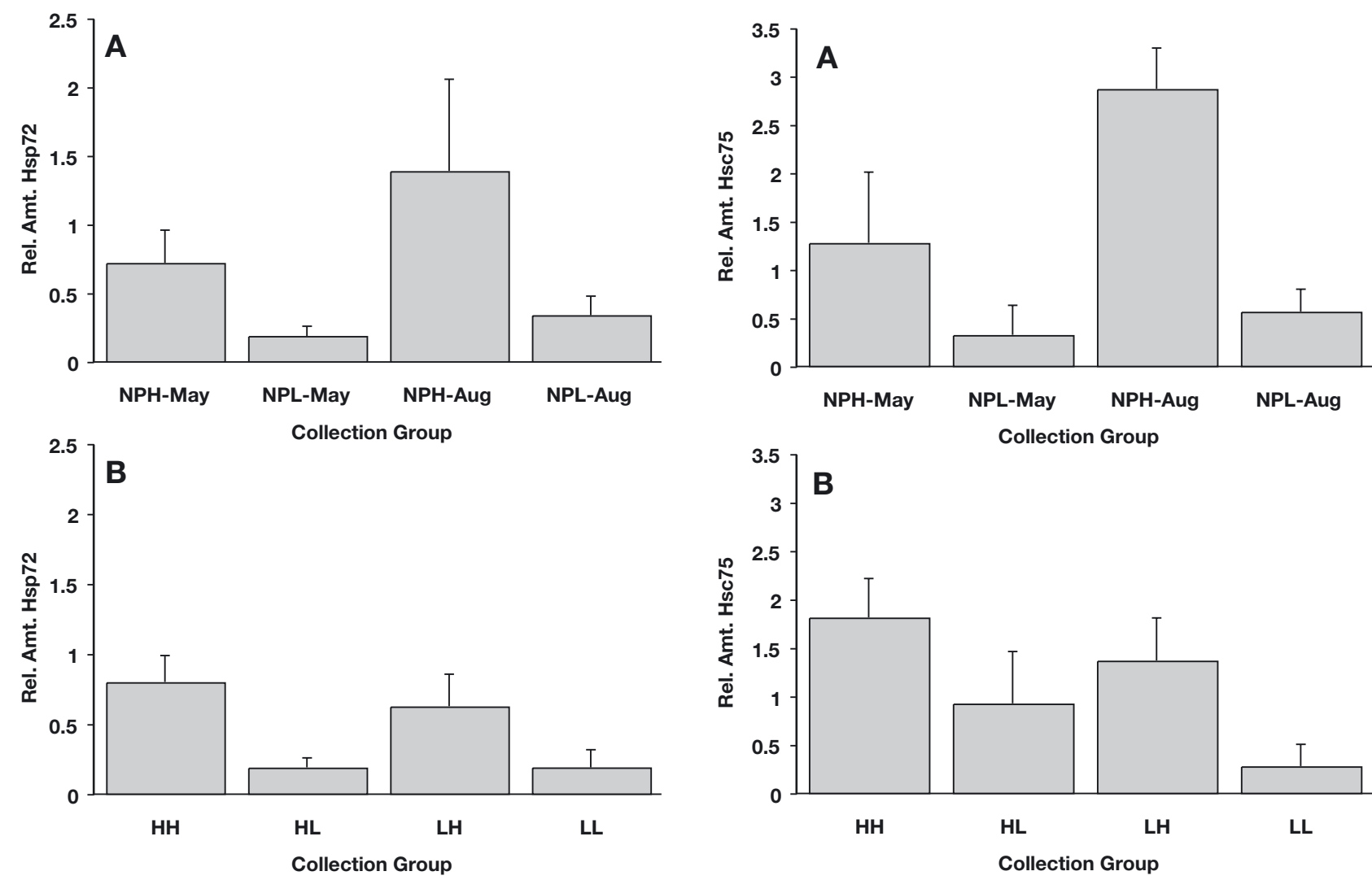

Fig. 4. Mytilus californianus. Levels of Hsp72 from natural and experimental populations. (A) Mussels from natural populations collected in May from the high (NPH-May) and low (NPL-May) mussel bed and in August from the high (NPHAug) and low (NPL-Aug) mussel bed. (B) Experimental mussels transplanted from the high back into the high $(\mathrm{HH})$, the high into the low (HL), the low into the high (LH) and the low back into the low (LL) area of the mussel bed. Bars indicate one standard error of the mean. $\mathrm{N}=6$ for all groups except LL, where $\mathrm{N}=4$

\section{DISCUSSION}

The induction temperature for Hsp70 synthesis has previously been shown to vary in response to recent thermal history. Blue mussels Mytilus trossulus exposed to colder or warmer conditions, both in nature and in experiments, exhibit altered induction temperatures and Hsp70 levels (Buckley et al. 2001). However, speciesspecific differences exist in the HSR, such as between the northerly distributed $M$. trossulus and the southerly distributed M. galloprovincialis, indicating a fundamental inflexibility that limits physiological plasticity (Hofmann \& Somero 1996a). Our results indicate that the HSR in $M$. californianus is highly plastic within the natural environment over small spatial scales (m). The induction temperature profile of mussels transplanted into the high-bed from the low-bed $\left(23.3\right.$ to $30.0^{\circ} \mathrm{C}$,

Fig. 5. Mytilus californianus. Levels of Hsc75 from natural and experimental populations. (A) Mussels from natural populations collected in May from the high (NPH-May) and low (NPL-May) mussel bed and in August from the high (NPHAug) and low (NPL-Aug) mussel bed. (B) Experimental mussels transplanted from the high back into the high $(\mathrm{HH})$, the high into the low (HL), the low into the high (LH) and the low back into the low (LL) area of the mussel bed. Bars indicate one standard error of the mean. $\mathrm{N}=6$ for all groups except $\mathrm{LL}$, where $\mathrm{N}=4$

Fig. 3B), closely resembled that of mussels transplanted back into the high-bed (24.8 to $27.0^{\circ} \mathrm{C}$, Fig. 3A) and unmanipulated mussels from the high-bed $\left(22.0\right.$ to $30.0^{\circ} \mathrm{C}$, Fig. 2B). In contrast, mussels transplanted from the highbed into the low-bed induced Hsp72 synthesis over a broad range $\left(15.0\right.$ to $27.0^{\circ} \mathrm{C}$, Fig. $\left.3 \mathrm{~B}\right)$, broader than the low-to-low transplanted mussels (19.0 to $23.3^{\circ} \mathrm{C}$, Fig. 3A) and almost as broad as all other mussels collected in $\mathrm{Au}-$ gust combined $\left(15.0\right.$ to $30.0^{\circ} \mathrm{C}$, Figs. $\left.2 \mathrm{~B} \& 3\right)$. These mussels display a range of response to their new environment with some mussels more closely resembling individuals from their native environment, the high-bed, and others resembling individuals from their new environment. This suggests that, while highly plastic, some constraints on the HSR may exist in organisms from closely spaced but physically disparate microhabitats such as the high and low shore. 
Few previous studies have transplanted organisms within the natural environment to examine alteration in the HSR, though previous studies on marine animals have compared field to laboratory acclimated organisms (Tomanek \& Somero 1999, 2002, Buckley et al. 2001), or compared field-collected organisms from different microhabitats and collection periods (Hofmann \& Somero 1995, Roberts et al. 1997, Halpin et al. 2002). In one of the few examples, Mytilus edulis transplanted from the Baltic to North Sea and subsequently exposed to copper in the laboratory, exhibited stress protein levels similar to mussels native to the North Sea site (Tedengren et al. 1999), indicating that the stress response to pollutants is highly plastic over a large spatial scale. Over a smaller spatial scale, individuals of the whelk species Nucella ostrina from a common source population outplanted into experimental cages placed in different within-site habitats (exposed and protected from wave action), and to a site with poorer prey quality, had Hsp70 levels that differed between habitats and sites as well as over time (Dahlhoff et al. 2001). Provision of shelter from heat stress (shade) lowered Hsp70 expression (Dahlhoff et al. 2001). Our results, of a fully reciprocal transplant, indicate that individuals from microhabitats only meters apart can have significantly different Hsp72 and Hsc75 levels over time, as has been observed previously in this species (Roberts et al. 1997, Halpin et al. 2002). Though the small spatial scale was small, it encompassed the intertidal vertical range of the mussels, showing that magnitude of spatial scale may not reflect magnitude of response.

In Mytilus californianus, the inducible and constitutive forms of Hsp70 can be visualized in a western blot due to differences in molecular mass (Roberts et al. 1997, Helmuth \& Hofmann 2001). This creates an advantage in the use of $M$. californianus as a 'model' marine organism, as one can explicitly test hypotheses about the inducible, stress-specific isoform, Hsp72. Here we observed that both the constitutive and inducible forms of Hsp70 were expressed at higher levels in high-bed mussels. The higher levels of Hsp72 are a direct indication that these mussels were experiencing greater protein damage than lowbed mussels. Additionally, we observed that 3 mussels from the high-bed ( 2 from NPH-Aug and 1 from $\mathrm{HH}$ ), but none from the low-bed, were heat shocked and synthesizing Hsp72 prior to their collection. This supports the hypothesis that high-bed mussels are at greater risk of thermal damage. The constitutive form, while not specifically synthesized in response to protein damage, can nonetheless confer increased thermal tolerance (Feder \& Hofmann 1999), which may help to explain its increased levels in high-bed mussels. However, elevated levels may also indicate other processes requiring enhanced protein chaperoning capacity, such as elevated levels of protein turnover.

The mechanisms that underlie the plasticity in the temperature of transactivation of Hsp genes are not entirely understood. However, the plasticity is most likely related to the behavior of a key transcriptional factor, heat shock factor 1 (HSF1) and its interaction with regulatory processes in the cell (for a review see Morimoto, 1998). Key among these appears to be the temperature-responsiveness of the activity of HSF1 itself. In marine gobies, the temperature of HSF1 activation changes with acclimation temperature of the fish, although how the temperature change transduces to changes in gene expression remains unclear (Buckley et al. 2001, Buckley \& Hofmann 2002). Research in model systems has supported a 'cellular thermometer' model where Hsps act as regulatory molecules and mediate the ability of HSF1 to activate stress-inducible Hsp gene expression, thereby controlling their own expression via a negative feedback loop (Craig \& Gross 1991, Morimoto 1998). This regulatory hypothesis leads to the prediction that total cellular levels of Hsps should correlate with Hsp induction temperatures such that, as Hsps increase in concentration, the Hsp threshold induction temperature should be driven higher. Again in a study on marine gobies, this relationship has been observed-higher levels of Hsps correlated with the alterations in HSF1 activity and Hsp gene activation (Buckley \& Hofmann 2004). Likewise, supporting evidence for a regulatory role of Hsp levels in Hsp induction temperature was also found in marine snails (Tegula spp., Tomanek 2002). Finally, although the current study does not provide data regarding the change in HSF1 activity, our data do indicate that mussels are able to shift their Hsp gene expression patterns within a period of $12 \mathrm{wk}$, the duration of this experiment. Although the rate of change of the 'thermostat' in mussels is unknown, it has been shown to change relatively quickly - in the order of days in the marine snail Tegula rugosa (M. Dueck \& G. E. Hofmann unpubl. data).

In summary, our investigation demonstrates that the HSR is highly plastic over small spatial scales and between physically distinct microhabitats. Induction temperatures, and the inducible and constitutive forms of Hsp70 changed with microhabitat. Mussels within the higher intertidal portions of their range experience higher levels of protein damage than those from the low-bed, as indicated by higher Hsp72 levels. However, the large range of induction temperatures exhibited by mussels transplanted from the high-bed to the low-bed give an indication that some individuals may have limits on their ability to adjust their HSR to new environments. 
Acknowledgements. The authors would like to thank J. Britt, B. A. Buckley, M. Foley, R. Milston, J. Pamplin, S. Place, and C. Sorte and for field and laboratory assistance. This research was supported by a National Science Foundation grant (IBN 0097871 to G.E.H.), funds from Susan and Bruce Worster (to G.E.H.), the Andrew J. Mellon Foundation (to B.A.M.), and the David and Lucile Packard Foundation (to B.A.M.). This is contribution number 152 of the Partnership for Interdisciplinary Studies of Coastal Oceans (PISCO): A Long-Term Ecological Consortium funded by the David and Lucile Packard Foundation.

\section{LITERATURE CITED}

Bayne BL (ed) (1976) Marine mussels: their ecology and physiology. Cambridge University Press, Cambridge

Bayne BL, Bayne CJ, Carefoot TC, Thompson RJ (1976) Physiological ecology of Mytilus californianus Conrad. 1. Metabolism and energy-balance. Oecologia 22:211-228

Bettencourt BR, Feder ME, Cavicchi S (1999) Experimental evolution of Hsp70 expression and thermotolerance in Drosophila melanogaster. Evolution 53:484-492

Buckley BA, Hofmann GE (2002) Thermal acclimation changes DNA-binding activity of heat shock factor 1 (HSF1) in the goby Gillichthys mirabilis: implications for plasticity in the heat-shock response in natural populations. J Exp Biol 205:3231-3240

Buckley BA, Hofmann GE (2004) Seasonal patterns and in vitro kinetics of HSF1 activation and Hsp70 mRNA production in the goby, Gillichthys mirabilis. Physiol Biochem Zool (in press)

Buckley BA, Owen ME, Hofmann GE (2001) Adjusting the thermostat: The threshold induction temperature for the heat-shock response in intertidal mussels (genus Mytilus) changes as a function of thermal history. J Exp Biol 204: 3571-3579

Coe WR, Fox DL (1942) Biology of the California sea-mussel (Mytilus californianus). J Exp Zool 90:1-30

Craig EA, Gross CA (1991) Is Hsp70 the cellular thermometer? Trends Biochem Sci 16:135-140

Dahlhoff EP, Rank NE (2000) Functional and physiological consequences of genetic variation at phosphoglucose isomerase: heat shock protein expression is related to enzyme genotype in a montane beetle. Proc Natl Acad Sci USA 97:10056-10061

Dahlhoff EP, Buckley BA, Menge BA (2001) Physiology of the rocky intertidal predator Nucella ostrina along an environmental stress gradient. Ecology 82:2816-2829

Elvin DW, Gonor JJ (1979) Thermal regime of an intertidal Mytilus californianus Conrad population on the central Oregon coast. J Exp Mar Biol Ecol 39:265-279

Feder ME (1999) Organismal, ecological, and evolutionary aspects of heat-shock proteins and the stress response: established conclusions and unresolved issues. Am Zool 39:857-864

Feder ME, Hofmann GE (1999) Heat-shock proteins, molecular chaperones, and the stress response: evolutionary and ecological physiology. Annu Rev Physiol 61:243-282

Gosling E (ed) (1992) The mussel Mytilus: ecology, physiology, genetics and culture. Elsevier, Amsterdam

Halpin PM, Sorte CJ, Hofmann GE, Menge BA (2002) Patterns of variation in levels of Hsp70 in natural rocky shore populations from microscales to mesoscales. Integr Comp Biol 42:815-824

Helmuth BST (1998) Intertidal mussel microclimates: predicting the body temperature of a sessile invertebrate. Ecol Monogr 68:29-52
Helmuth B (1999) Thermal biology of rocky intertidal mussels: quantifying body temperatures using climatological data. Ecology 80:15-34

Helmuth B (2002) How do we measure the environment? Linking intertidal thermal physiology and ecology through biophysics. Integr Comp Biol 42:837-845

Helmuth BST, Hofmann GE (2001) Microhabitats, thermal heterogeneity, and patterns of physiological stress in the rocky intertidal zone. Biol Bull (Woods Hole) 201:374-384

Hofmann GE, Somero GN (1995) Evidence for protein damage at environmental temperatures: seasonal changes in levels of ubiquitin conjugates and Hsp70 in the intertidal mussel Mytilus trossulus. J Exp Biol 198:1509-1518

Hofmann GE, Somero GN (1996a) Interspecific variation in thermal denaturation of proteins in the congeneric mussels Mytilus trossulus and M. galloprovincialis: evidence from the heat-shock response and protein ubiquitination. Mar Biol 126:65-75

Hofmann GE, Somero GN (1996b) Protein ubiquitination and stress protein synthesis in Mytilus trossulus occurs during recovery from tidal emersion. Mol Mar Biol Biotechnol 5: $175-184$

Iwasaki K (1995) Factors delimiting the boundary between vertically contiguous mussel beds of Septifer virgatus (Wiegmann) and Hormomya mutabilis (Gould). Ecol Res 10:307-320

Krebs RA, Bettencourt BR (1999) Evolution of thermotolerance and variation in the heat shock protein, Hsp70. Am Zool 39:910-919

Lindquist S (1986) The heat shock response. Annu Rev Biochem 55:1151-1191

Menge BA (1992) Community regulation: under what conditions are bottom up factors important in rocky shores? Ecology 73:755-765

Menge BA (2000) Top-down and bottom-up community regulation in marine rocky intertidal habitats. J Exp Mar Biol Ecol 250:257-289

Menge BA, Berlow EG, Blanchette CA, Navarrete SA, Yamada SB (1994) The keystone species concept: variation in interaction strength in a rocky intertidal habitat. Ecol Monogr 64:249-286

Menge BA, Daley BA, Wheeler PA, Dahlhoff E, Sanford E, Strub PT (1997a) Benthic-pelagic links and rocky intertidal communities: bottom-up effects on top-down control? Proc Natl Acad Sci USA 94:14530-14535

Menge BA, Daley BA, Wheeler PA, Strub PT (1997b) Rocky intertidal oceanography: an association between community structure and nearshore phytoplankton concentration. Limnol Oceanogr 42:57-66

Moon TW, Pritchard AW (1970) Metabolic adaptations in vertically separated populations of Mytilus californianus Conrad. J Exp Mar Biol Ecol 5:35-46

Morimoto RI (1998) Regulation of the heat shock transcriptional response: cross talk between a family of heat shock factors, molecular chaperones, and negative regulators. Genes Dev 12:3788-3796

Paine RT (1974) Intertidal community structure: experimental studies on the relationship between a dominant competitor and its principal predator. Oecologia 15:93-120

Paine RT (1976) Size-limited predation: an observational and experimental approach with the Mytilus-Pisaster interaction. Ecology 57:858-873

Roberts DA, Hofmann GE, Somero GN (1997) Heat-shock protein expression in Mytilus californianus: acclimatization (seasonal and tidal-height comparisons) and acclimation effects. Biol Bull (Woods Hole) 192:309-320

Robles CD (1997) Changing recruitment in constant species 
assemblages: implications for predation theory in intertidal communities. Ecology 78:1400-1414

Sagarin RD, Gaines SD (2002) Geographical abundance distributions of coastal invertebrates: using one-dimensional ranges to test biogeographic hypotheses. J Biogeogr 29: 985-997

Suchanek TH (1978) Ecology of Mytilus edulis L in exposed rocky intertidal communities. J Exp Mar Biol Ecol 31: 105-120

Tedengren M, Olsson B, Bradley B, Zhou LZ (1999) Heavy metal uptake, physiological response and survival of the blue mussel (Mytilus edulis) from marine and brackish waters in relation to the induction of heat-shock protein 70. Hydrobiologia 393:261-269

Tomanek L (2002) The heat-shock response: its variation, regulation and ecological importance in intertidal gastropods (genus Tegula). Integr Comp Biol 42:797-807

Tomanek L, Somero GN (1999) Evolutionary and acclimationinduced variation in the heat-shock responses of congeneric marine snails (genus Tegula) from different thermal habitats: implications for limits of thermotolerance

Editorial responsibility: Otto Kinne (Editor),

Oldendorf/Luhe, Germany and biogeography. J Exp Biol 202:2925-2936

Tomanek L, Somero GN (2000) Time course and magnitude of synthesis of heat-shock proteins in congeneric marine snails (genus Tegula) from different tidal heights. Physiol Biochem Zool 73:249-256

Tomanek L, Somero GN (2002) Interspecific- and acclimationinduced variation in levels of heat-shock proteins 70 (Hsp70) and 90 (Hsp90) and heat-shock transcription factor-1 (HSF1) in congeneric marine snails (genus Tegula): implications for regulation of Hsp gene expression. J Exp Biol 205:677-685

Tsuchiya M (1983) Mass mortality in a population of the mussel Mytilus edulis L. caused by high temperature on rocky shores. J Exp Mar Biol Ecol 66:101-111

Widdows J, Shick JM (1985) Physiological responses of Mytilus edulis and Cardium edule to aerial exposure. Mar Biol 85:217-232

Widdows J, Bayne BL, Livingstone DR, Newell RIE, Donkin P (1979) Physiological and biochemical responses of bivalve mollusks to exposure to air. Comp Biochem Physiol A 62: 301-308

Submitted: September 18, 2003; Accepted: April 22, 2004

Proofs received from author(s): July 6, 2004 